\title{
Novel recombinant monoclonal antibodies for vitellogenin assays in cyprinid fish species
}

\author{
Yu Rao ${ }^{1,2}$, Liqiao Zhong ${ }^{1,2}$, Tao Liao ${ }^{1}$, Shiwei Jin $^{1}$, Yuzhen Wang ${ }^{1}$, Bo Song ${ }^{1}$, \\ Jia Li ${ }^{1,2}$, Xiaohua Zhang ${ }^{1}$, Sean M. Hemmingsen ${ }^{3}$, Ying Xu ${ }^{1}$, Heping Dai ${ }^{1, *}$ \\ ${ }^{1}$ Institute of Hydrobiology, Chinese Academy of Sciences, 7 Southern East Lake Road, \\ Wuchang, Wuhan, Hubei 430072, PR China \\ ${ }^{2}$ Graduate School of the Chinese Academy of Sciences, Yuquan Road 19A, Beijing 100039, PR China \\ ${ }^{3}$ Plant Biotechnology Institute, National Research Council of Canada, 110 Gymnasium Place, \\ Saskatoon, Saskatchewan, S7N 0W9, Canada
}

\begin{abstract}
Various polyclonal and monoclonal antibodies have been developed for vitellogenin (Vtg) bioassays in different aquatic species. Preparation of these reagents is time-consuming and expensive. In the present study, a phage-displayed, recombinant, single-chain variable fragment ( $\mathrm{scFv}$ ) format antibody library was constructed using splenic mRNA from non-immunized mice. After 3 rounds of panning, $3 \mathrm{scFv}$ antibodies with specificity for the highly conserved N-terminal region of cyprinid fish Vtg were isolated. One of these, antibody H4, bound purified Vtg from common carp Cyprinus carpio, zebrafish Danio rerio and Chinese rare minnow Gobiocypris rarus with similar affinities and detected Vtg in zebrafish plasma samples. This study provides a simple, low cost Vtg bioassay for plasma samples from a variety of cyprinid fish.
\end{abstract}

KEY WORDS: Vitellogenin detection · Cyprinid fish $\cdot$ Phage display $\cdot$ ScFv antibody $\cdot$ Bioassay • Binding affinity

Resale or republication not permitted without written consent of the publisher

\section{INTRODUCTION}

A wide variety of endocrine disrupting compounds (EDCs), potentially capable of disrupting development and reproduction in humans and wildlife, are present in the aquatic environment (Colborn et al. 1996). This has attracted international attention for several decades and a number of methods for detecting EDCs have been developed and validated (Muncke \& Eggen 2006).

In female oviparous animals, vitellogenin (Vtg), the phospholipoglycoprotein precursor to the major egg yolk protein, is synthesized in the liver in response to endogenous estrogen (Wallace 1985, Specker \& Sullivan 1994). In teleost fish, while Vtg is generally present in minute quantities in males or juvenile females (usually $\mathrm{ng} \mathrm{ml}^{-1}$, occasionally up to a few $\mu \mathrm{g} \mathrm{m}^{-1}$ ) (Copeland et al. 1986), its synthesis can be induced by exposure to estrogen or estrogen mimics. Thus, the presence of Vtg in male or juvenile female fish has become a popular biomarker for measuring exposure of oviparous animals to estrogen or estrogen mimics (Sumpter \& Jobling 1995, Holbech et al. 2001, Panter et al. 2002, Darain et al. 2004, Muncke \& Eggen 2006). In the Organisation for Economic Cooperation and Development (OECD) Guidelines for the Testing of Chemicals (TGs) 229 and 230 (OECD 2009a,b), the identification of Vtg induction has become an obligatory component.

Various kinds of immunoassay techniques have been developed to measure Vtg, such as radioimmunoassay (RIA) (Tyler \& Sumpter 1990), simultaneous chemiluminescent immunoassay (CLIA) (Fukada et al. 2003), optical immunosensor (Bulukin et al. 2007), enzymelinked immunoassay (ELISA), immunodiffusion, and alkali-labile phosphate (Pereira et al. 1992). Among these, ELISA is the most popular tool. In the last decade, different ELISAs have been developed for Vtg detection in various fish species, such as fathead 
minnow Pimephales promelas (Mylchreest et al. 2003, Eidem et al. 2006), zebrafish Danio rerio (Fenske et al. 2001, Brion et al. 2002), carp Cyprinus carpio (Fukada et al. 2003), crucian carp Carassius auratus (An et al. 2007), golden grey mullet Liza aurata (Asturiano et al. 2005), perch Perca fluviatilis (Hennies et al. 2003), Chinese rare minnow Gobiocypris rarus (Zhong et al. 2004), and Japanese medaka Oryzias latipes (Nilsen et al. 2004).

Cyprinid fish are widely distributed and have been shown to act as excellent sentinel species for endocrine influences in surface waters (Folmar et al. 1996, Jobling et al. 1998). The Vtg molecule, including the $\mathrm{N}$-terminal region, is highly conserved within the cyprinid family (Folmar et al. 1995, Heppell et al. 1995). Based on this, polyclonal and monoclonal antibodies have been developed that have specificity for Vtg from a wide variety of cyprinid fish (Tyler \& Sumpter 1990, Tyler et al. 1996) and even from 4 vertebrate classes (fish, amphibians, reptiles, and birds) (Heppell et al. 1995). These antibodies have been used in many applications. However, preparation of the polyclonal and monoclonal antibodies is time-consuming and rigorously controlled conditions are required (for eukaryotic cell culture or animal immunization). Development of a low-cost and sensitive Vtg detection method would be of great importance for meeting current requirements.

Phage-display technology enables the production in Escherichia coli of large amounts of recombinant antibodies, including the single-chain variable fragment (scFv) format (Hoogenboom et al. 1998). These antibodies can be developed quickly and cheaply from phage-display antibody libraries, often without the need to immunize animals. Phage-display technology has not been used so far to develop antibodies for Vtg detection. The aim of this study was to produce $\mathrm{scFv}$ antibodies by phage display for Vtg bioassays for different cyprinid species. The resulting antibodies allow low-cost detection of Vtg in plasma samples from cyprinid fish and serve as the basis for further development of a universal detection method for Vtg from different cyprinid fish to monitor exposure to estrogen mimics in the aquatic environment.

\section{MATERIALS AND METHODS}

Experimental animals. Adult male zebrafish Danio rerio, Chinese rare minnow Gobiocypris rarus, common carp Cyprinus carpio and crucian carp Carassius auratus were bred and maintained in the laboratory. Purified Vtg from common carp, zebrafish and rare minnow and rabbit antiserum against Vtg of zebrafish were provided by T. Liao (Liao et al. 2006).
Hormone treatment and blood sampling. Groups of 20 adult male zebrafish (average body mass $318 \pm$ $128 \mathrm{mg}, \mathrm{n}=160$ ) were distributed into 8 aquaria (10 l each). Each group of fish was acclimated for $1 \mathrm{wk}$ prior to use. Fish were maintained in a 14:10 h light:dark cycle at 22 to $25^{\circ} \mathrm{C}$ and fed earthworms once per day. Groups of fish were exposed for $7 \mathrm{~d}$ to $17 \alpha$ ethynylestradiol (EE2, Sigma) at 0, 2, 4, 8, 16, 32, 64 or $128 \mathrm{ng} \mathrm{l}^{-1}$ from a stock solution of $1 \mathrm{~g} \mathrm{l}^{-1}$ EE2 in dimethyl sulphoxide (DMSO, Sigma). DMSO only was added to the control group. The final DMSO concentration was $<0.01 \%$ by volume in all cases. After exposure, fish were weighed and blood was collected as described by Liao et al. (2006). Sera were stored at $-80^{\circ} \mathrm{C}$. Plasma protein was measured by the Bradford method (Harlow \& Lane 1999).

Cloning, expression and product purification of $\mathrm{Vtg}$ conserved region. Vtg amino acid sequences of several cyprinid fish were aligned using DNAStar and a conserved N-terminal region of 152 residues (named VI) was identified (Fig. 1). This region, spanning residues 6 to 157 of the zebrafish protein Vtg (Z-Vtg), was $91.4 \%$ identical in Chinese rare minnow Vtg (R-Vtg), 92.8\% in fathead minnow Vtg (F-Vtg), 88.8\% in common carp Vtg (C-Vtg), and $87.4 \%$ in crucian carp Vtg (G-Vtg). The conserved primary structure of this region of the protein indicated that it was a potential target for anti-Vtg antibodies for cyprinid fish species in general.

Poly(A)+ RNA purified from livers of 10 adult female zebrafish that were exposed to $100 \mathrm{ng} \mathrm{l}^{-1} \mathrm{EE} 2$ for $7 \mathrm{~d}$ was reverse transcribed in vitro using random hexamers and a First Strand cDNA Synthesis Kit (Promega). A VI cDNA sequence was amplified by PCR using primers VI-P1 and VI-P2 (5' -CCG GAA TTC CTT GCC TTG ACT GTA GCC C-3' and 5'-CCG CTC GAG TTC CAG CCT CTT GCA TCT C-3', respectively; EcoRI and $\mathrm{XhoI}$ restriction sites are underlined). PCR conditions were $94^{\circ} \mathrm{C}$ for $5 \mathrm{~min}, 30$ cycles of denaturation for $45 \mathrm{~s}$ at $94^{\circ} \mathrm{C}$, annealing for $30 \mathrm{~s}$ at $54^{\circ} \mathrm{C}$ and extension for $1 \mathrm{~min}$ at $72^{\circ} \mathrm{C}$, followed by a final extension for 5 min at $72^{\circ} \mathrm{C}$. After digestion with EcoRI and XhoI, the VI sequence was cloned into expression vector pET$32 \mathrm{a}$ as an in-frame fusion with thioredoxin, His, and Sprotein tags (referred to as 32a-VI), and into pET-28a as a fusion with His and T7 tags (28a-VI). The correct recombinant plasmids were identified by PCR and confirmed by DNA sequencing. The recombinant proteins, 32a-VI ( 34 kDa) and 28a-VI ( 24.5 kDa) were biosynthesized in Escherichia coli origami (ED3) cells as described in the pET system manual (Novagen) and purified with His-Bind Resin (Novagen). The recombinant proteins were detected by SDS-PAGE and western blotting.

Phage-display scFv antibody library construction. Spleenic poly(A)+ RNA from 100 non-immunized 


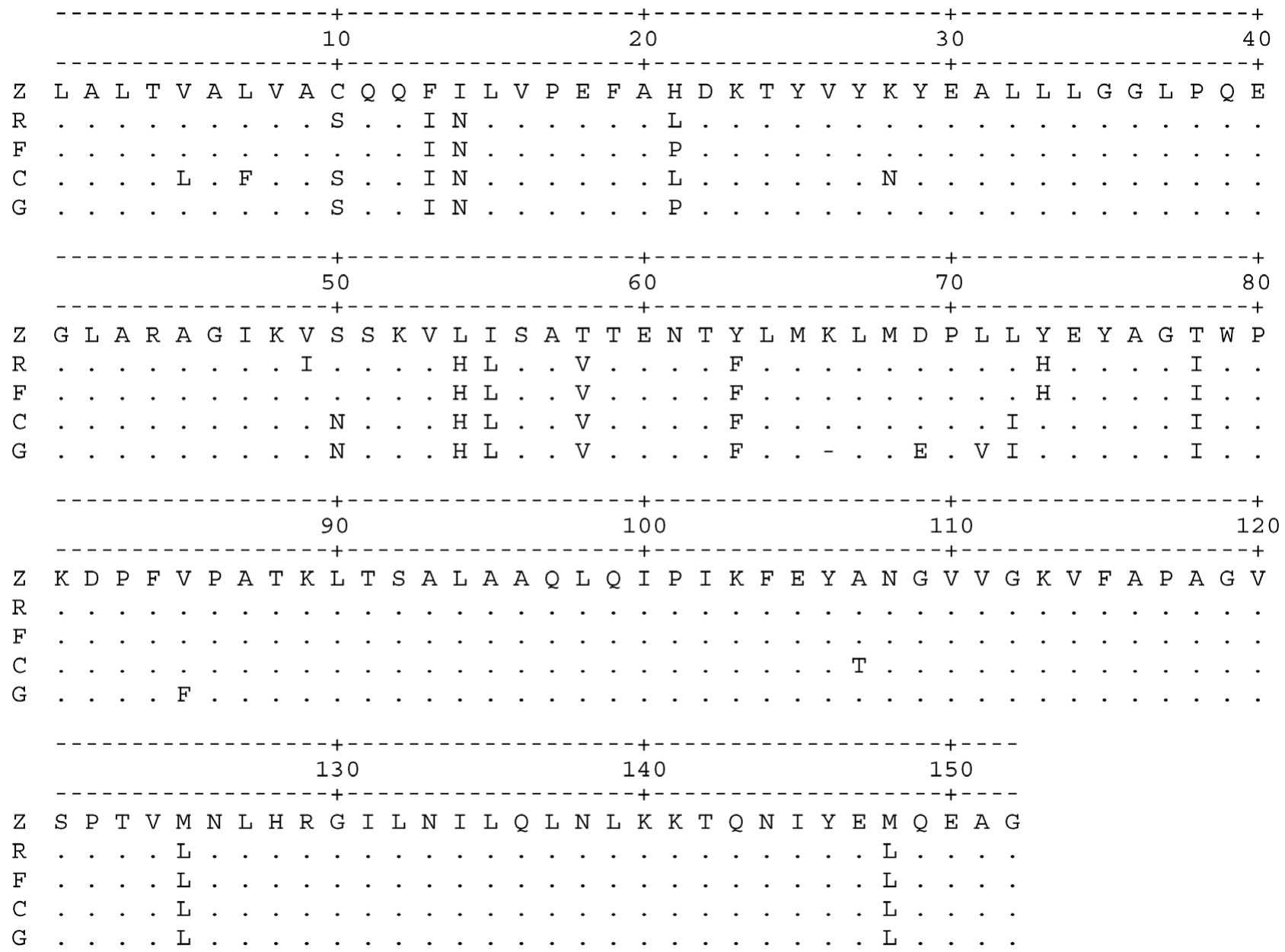

Fig. 1. Aligned N-terminal vitellogenin sequences of cyprinid fish. (Z) Zebrafish Danio rerio (GenBank accession no.: CAK03614); (R) Chinese rare minnow Gobiocypris rarus (GenBank accession no.: EU623080); (F) fathead minnow Pimephales promelas (GenBank accession no.: AAD23878); (C) common carp Cyprinus carpio (GenBank accession no.: BAD51933); (G) crucian carp Carassius auratus (GenBank accession no.: ABG22139). Periods indicate residues that are identical to the residue in zebrafish. Dash indicates an introduced gap

6 wk old female BAL b/c mice was reverse transcribed in vitro using random hexamers and a First Strand cDNA Synthesis Kit (Promega). $V_{H}$ and $V_{L}$ regions were amplified from the cDNA, assembled with a flexible linker coding region and ligated into a phagemid vector, pCANTAB 5E (Pharmacia), as described by Barbas et al. (2001). Escherichia coli NM522 cells were transformed by electroporation with the ligation products. Recombinant phage were rescued by superinfection with M13K07 helper phage.

Subtractive panning of phage and production of soluble scFv antibodies against VI fragment. Phage with binding specificity for the recombinant Vtg protein 32a-VI were selected by a subtractive panning approach. Nunc immunotest tubes (Inter Med) were coated overnight at $4^{\circ} \mathrm{C}$ with purified 32a-VI protein $(100 \mu \mathrm{g}$ in $5 \mathrm{ml})$, or with a crude extract $(5 \mathrm{ml})$ from cells carrying the empty pET-32a vector, then blocked for $1 \mathrm{~h}$ at $37^{\circ} \mathrm{C}$ with $4 \%$ PBSM ( $4 \%$ skim milk in PBS). A suspension of rescued recombinant phage $(2.5 \mu \mathrm{l}$ plus $2.5 \mu \mathrm{l} 10 \%$ PBSM) was added to the crude extractcoated tube. After $1 \mathrm{~h}$ at $37^{\circ} \mathrm{C}$, the supernatant containing unbound phage was transferred to the purified $32 \mathrm{a}-\mathrm{VI}$ protein-coated tube. After $1 \mathrm{~h}$ at $37^{\circ} \mathrm{C}$, the supernatant was discarded and the tube was rinsed 20 times with PBST (PBS containing $0.1 \%$ Tween 20) and 20 times with PBS. Bound phage were eluted from the tube with $1 \mathrm{ml} 100 \mathrm{mM}$ triethylamine. After transfer to a new tube, the solution was neutralized by addition of $0.5 \mathrm{ml}, 1 \mathrm{M}$ Tris- $\mathrm{HCl}$ (pH 7.5), $0.5 \mathrm{ml} 10 \%$ PBSM was added and the resulting $2 \mathrm{ml}$ suspension of phage were transferred to a new crude extract-coated tube and incubated for $20 \mathrm{~min}$ at $37^{\circ} \mathrm{C}$. The unbound phage were mixed with Escherichia coli TG1 cells and spread 
on SOBAG plates (Amersham Biosciences Expression Module), which were incubated overnight at $30^{\circ} \mathrm{C}$. Three rounds of panning were conducted in this manner. Similarly, phage were selected with binding specificity for the recombinant Vtg protein 28a-VI. Soluble $\mathrm{scFv}$ antibodies were purified from extracellular or periplasmic extracts from each selected clone according to the Pharmacia Expression Module manual. Antibodies were assessed for antigen binding by ELISA.

Western blotting. Protein extracts from fish samples were separated by SDS-PAGE in $12 \%$ or $8 \%$ gels and then the polypeptides were transferred to a nitrocellulose membrane. The membrane was blocked with $4 \%$ PBSM and then incubated with soluble scFv antibody for $1 \mathrm{~h}$ at room temperature (RT). After 5 rinses with PBST and 5 rinses with PBS, the bound antibody was detected with a mouse monoclonal antibody HRP/antiE Tag conjugate (1:10 000, Amersham Biosciences) for $1 \mathrm{~h}$ at RT. Color development was in substrate buffer containing 3,3-diaminobenzidine (DAB, Amresco).

ELISA. The direct ELISA protocol was based on the method described by Denslow et al. (1999). Purified ZVtg was used as the standard. The standard Vtg were diluted with PBS ( $\mathrm{pH} 7.2$ ) to 31.25-32 $000 \mathrm{ng}$ protein $\mathrm{ml}^{-1}$. The influence of matrix was tested using plasma samples from non-exposed male zebrafish. The minimal dilution factor needed to avoid the matrix effect is $1 / 200(\mathrm{v} / \mathrm{v})$. The plasma samples were diluted in the range $1 / 200$ to $1 / 5000(\mathrm{v} / \mathrm{v})$ with $\mathrm{PBS}(\mathrm{pH} 7.2)$ in Vtg quantification assay. After dilution, samples were pipetted in triplicate into a 96-well microplate $(100 \mu \mathrm{l}$ per well). The plate was coated overnight at $4{ }^{\circ} \mathrm{C}$, blocked with $4 \%$ PBSM (340 $\mu$ l per well) for $1 \mathrm{~h}$ at $37^{\circ} \mathrm{C}$, washed with PBS and incubated with ScFv antibody for $1 \mathrm{~h}$ at $37^{\circ} \mathrm{C}(100 \mu \mathrm{l}$ per well). After washing 3 times each with PBST and PBS, the bound SCFv antibody was recognized with HRP/Anti-E Tag conjugate (1:10 000). Finally, 3, 3', 5, 5'-tetramethylbenzidine (TMB, Serva) was used for the color reaction with peroxidase and the absorbance at $450 \mathrm{~nm}\left(\mathrm{OD}_{450 \mathrm{~nm}}\right)$ was determined.

A linear response was observed in the range 50 to $1600 \mathrm{ng} \mathrm{ml}^{-1}$ purified Vtg standard $(y=0.0009 x$ $-0.048, R^{2}=0.9957$ ) and the sensitivity of the ELISA was $50 \mathrm{ng} \mathrm{ml}^{-1}$ (Fig. 2A). The detection sensitivity of Vtg was defined as the lowest concentration of standard yielding a mean $\mathrm{OD}_{450 \mathrm{~nm}}$ value that was significantly different (Student's $t$-test; $\mathrm{p}<0.01$ ) from that obtained with blank incubations. The upper limit of detection was defined as the maximum standard concentration falling in the linear region of the standard curves. The good parallelism between the dilution curve of plasma samples and the standard curve of purified Vtg demonstrated that this ELISA method can be used to quantify Vtg in plasma (Fig. 2B). The
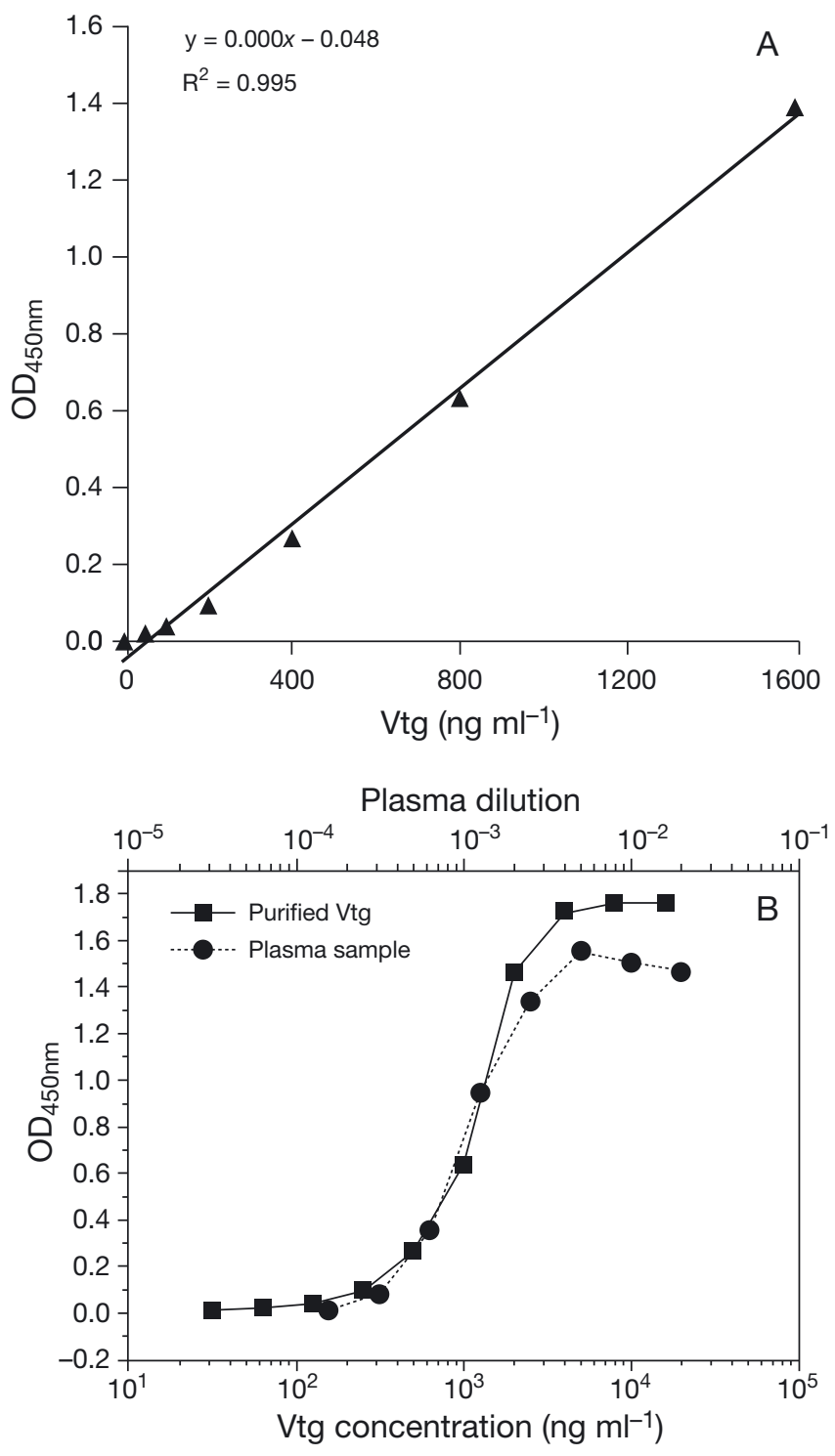

Fig. 2. (A) Standard curve of direct ELISA with soluble singlechain variable fragment (scFv) antibody $\mathrm{H} 4$ against purified zebrafish vitellogenin (Vtg). (B) ELISA of serial dilutions of (ם) purified zebrafish Vtg and (@) plasma from juvenile male zebrafish exposed to $128 \mathrm{ng} \mathrm{l}^{-1} \mathrm{EE} 2$ for $7 \mathrm{~d}$ with soluble $\mathrm{ScFv}$ antibody H4. Soluble recombinant antibody H4 was $25.4 \mu \mathrm{g} \mathrm{ml}^{-1}$

robustness of the ELISA method was assessed by interand intra-assay variation. Intra-assay variation was $3.5 \%$ and it was measured by adding the same internal standard to one microtiter plate 12 times. Inter-assay variation was $2.2 \%$ and it was measured by comparing various dilutions of the same internal standard added to 12 different microtiter plates.

Determination of affinity constants. The affinity constants $\left(K_{\mathrm{aff}}\right)$ of $\mathrm{scFv}$ antibodies to purified Z-Vtg, RVtg or C-Vtg immobilized on a 96-well microplate were estimated as described by Beatty et al. (1987). 


\section{RESULTS AND DISCUSSION}

\section{Selection of specific scFv antibodies against Vtg fragment 28a-VI}

Initially, three 6-wk-old female BAL b/c mice were immunized by pET 32a-VI protein with Freund adjuvant. A mouse 32a-VI scFv antibody phage-display library of 6.2 $\times 10^{6}$ clones was constructed using spleenic poly(A)+ RNA from the immunized mice (data not shown). ScFv antibodies with specificity for the Vtg 32aVI fragment were selected by subtractive panning, but most of these antibodies were found to be specific for the His- or Sprotein tags rather than the Vtg moiety, perhaps because of the large size ( 19 kDa) and high antigenicity of the tags. To reduce this problem, an $\mathrm{scFv}$ antibody phage-display library of $1.3 \times 10^{10}$ clones was constructed using splenic mRNA from non-immunized mice. This library has no bias to the tag protein of the pET 32a or pET 28a vectors. Meanwhile, the VI sequence was fused with the smaller tag present in pET28a ( 8 kDa). The crude fusion tag present in extracts from cells carrying the empty pET-28a vector was used for subtractive panning. After 3 rounds of panning, 58 clones that specifically bound the 28a-VI fusion protein were isolated. Nine of those specifically bound zebrafish Vtg. Six clones with higher affinity were sequenced. Three different clones with distinct $\mathrm{V}_{\mathrm{H}}$ segments were found (Table 1).

\section{Binding specificity of ScFv antibodies}

Three soluble scFv antibodies, B5, E7 and H4 (Table 1; GenBank accession numbers FJ792805, FJ792806, FJ792807), were purified from Escherichia coli TG1 cells and used for western blot and ELISA assays. B5 and H4 antibodies recognized the denatured 28a-VI polypeptide in western blotting, while the signal from E7 was faint or absent (Fig. 3A). This observation suggested that B5 and H4 may have recognized linear epitopes, whereas E7 may have recognized a conformational epitope. Cyprinid fish Vtg protein has 2 subunits, usually of approximately 147 and $170 \mathrm{kDa}$ (Parks et al. 1999, Fenske et al. 2001, Fukada et al.
2003, Zhong et al. 2004, Ma et al. 2005, Finn 2007). B5 and $\mathrm{H} 4$ recognized the 2 denatured Vtg polypeptides from zebrafish, Chinese rare minnow, common carp and crucian carp (Fig. 3B,C). Other polyclonal and monoclonal antibodies, also specific to Vtg from various cyprinid fish, show similar western blot results to B5 and H4 (Zhong et al. 2004, Li et al. 2005, Liao et al. 2006, Kang et al. 2007).

The binding specificities of $\mathrm{ScFV}$ antibodies B5 and $\mathrm{H} 4$ to the purified VI fragment were also determined

Table 1. Amino acid sequence of the $\mathrm{V}_{\mathrm{H}}$ region complementarity-determing regions $(\mathrm{CDR})$ of isolated single-chain variable $(\mathrm{scFv})$ antibodies specifically binding to the VI in zebrafish-vitellogenin

\begin{tabular}{|llll}
\hline scFv antibody & CDR1 & CDR2 & CDR3 \\
\hline B5 & GYTFTSYWMH & YINPSTGYTEYNQKFKD & TGTY \\
E7 & GYSFTGYNMN & NIDPYYGGTSYNQKFKG & TGAY \\
H4 & GYAFSSYWMN & QIYPGDGDTNYNGKFKG & TGDY \\
\hline
\end{tabular}
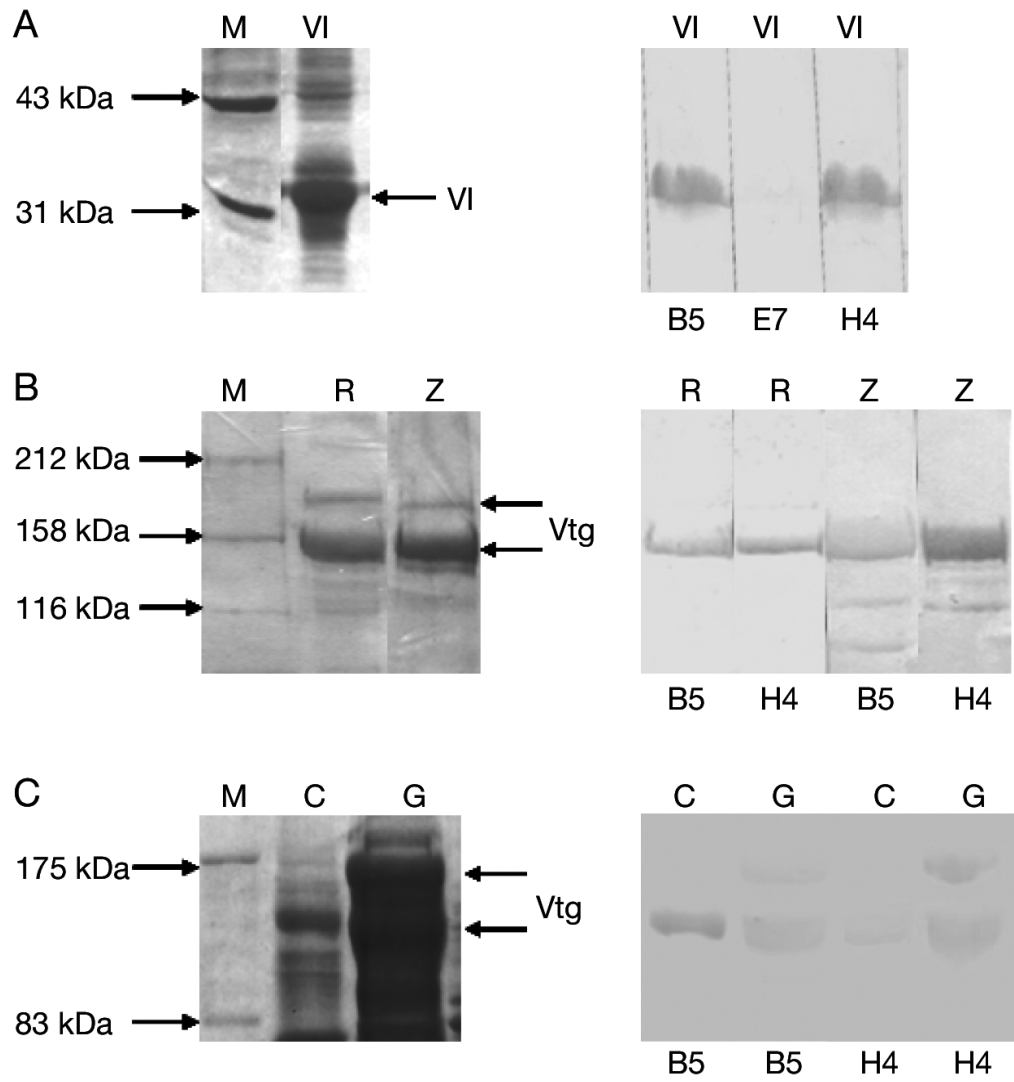

Fig. 3. Immunoblot analysis of single-chain variable fragment (scFv) antibodies against denatured vitellogenin (Vtg) polypeptides. Left: Coomassie Bluestained gels after SDS-PAGE. Right: immunoblots. (A) Recognition of purified VI fusion polypeptide by soluble scFv antibodies B5, E7 and H4 (B,C) Recognition of Vtg polypeptides present in adult female fish serum by soluble scFv antibodies B5 and H4. (M) Molecular weight standards, (VI) recombinant zebrafish Vtg (28a-VI) purified from Escherichia coli, (R) Chinese rare minnow Vtg, (Z) zebrafish Vtg, (C) common carp Vtg, (G) crucian carp Vtg 

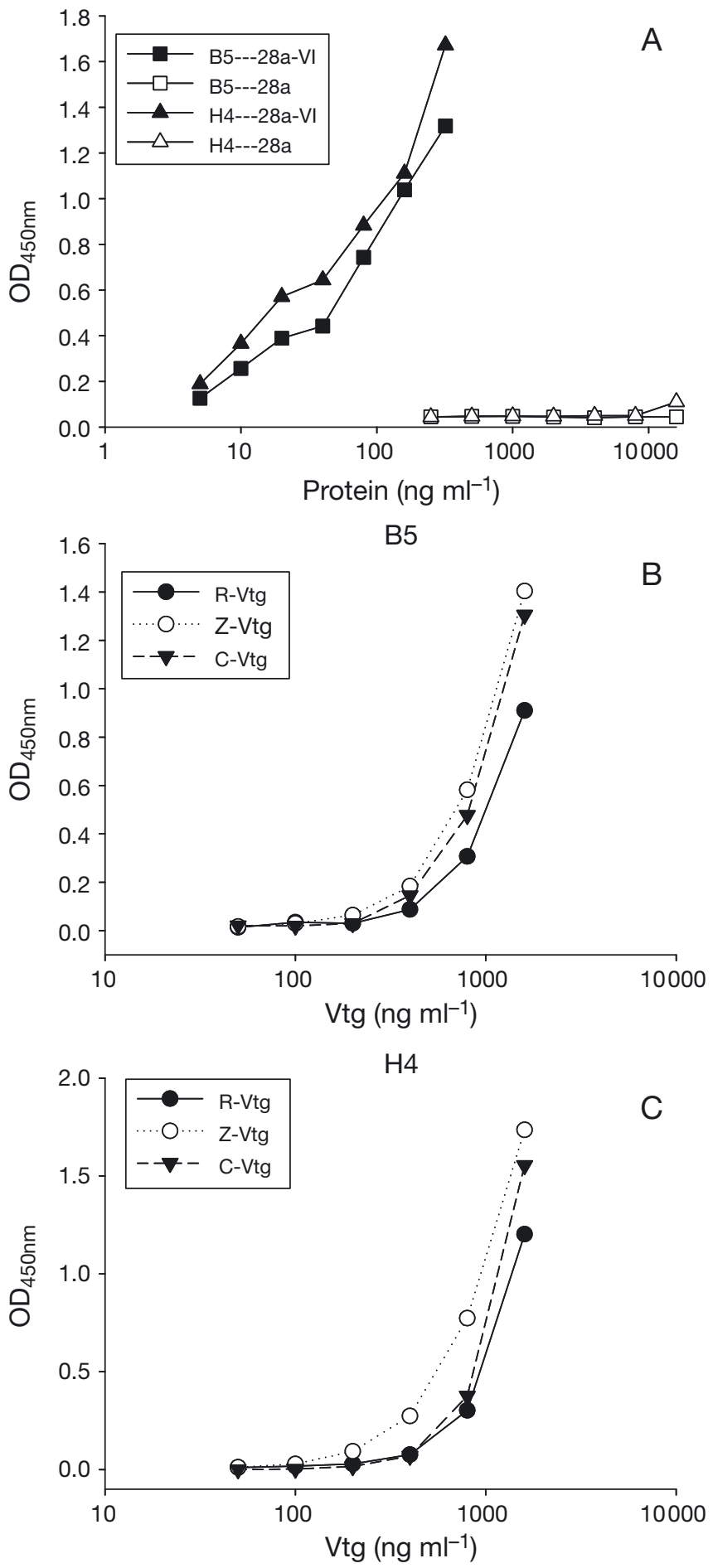

Fig. 4. ELISA analysis of binding specificity of soluble singlechain variable fragment ( $\mathrm{scFv}$ ) antibodies B5 and $\mathrm{H} 4$ to the VI peptide and to vitellogenin (Vtg) from various cyprinid fish species. (A) ( $\square$ ) B5 binding to purified 28a-VI; ( $\square$ ) B5 binding to control extracts containing the pET28a fusion tag; $(\mathbf{\Lambda}) \mathrm{H} 4$ binding to purified 28a-VI $(\Delta) \mathrm{H} 4$ binding to control extracts containing the pET28a fusion tag. (B) B5 binding to purified (•) R-Vtg from Chinese rare minnow, (O) Z-Vtg from zebrafish and ( $\boldsymbol{\nabla}) \mathrm{C}$-Vtg from common carp. (C) H4 binding to purified (•) R-Vtg, (O) Z-Vtg and ( $\mathbf{\nabla}) \mathrm{C}-\mathrm{Vtg}$
Table 2. Affinity constants $\left(K_{\mathrm{aff}}\right)$ of soluble single-chain variable fragment antibody H4 against vitellogenin (Vtg) from zebrafish (Z-Vtg), Chinese rare minnow (R-Vtg), and common carp (C-Vtg)

\begin{tabular}{|lc|}
\hline Vtg form & $K_{\mathrm{aff}}\left(\mathrm{mol}^{-1}\right)$ \\
\hline $\mathrm{Z}-\mathrm{Vtg}$ & $1.27 \pm 0.01 \times 10^{6}$ \\
$\mathrm{R}-\mathrm{Vtg}$ & $2.16 \pm 0.35 \times 10^{6}$ \\
$\mathrm{C}-\mathrm{Vtg}$ & $1.45 \pm 0.08 \times 10^{6}$ \\
\hline
\end{tabular}

by ELISA. B5 and H4 specifically recognized 28a-VI with little or no signal from the control extract from cells carrying the empty vector (Fig. 4A). Each antibody produced similar signals against Vtg purified from zebrafish, Chinese rare minnow, common carp and crucian carp (Fig. 4B,C).

The relative affinity constants $\left(K_{\text {aff }}\right)$ for $\mathrm{H} 4$ against Vtg from zebrafish, Chinese rare minnow and common carp are shown in Table 2. Values for H4 against these 3 different Vtg were in the same order of magnitude, which suggested that $\mathrm{H} 4$ could measure Vtg in these cyprinid species with similar sensitivities.

\section{ELISA of plasma Vtg after exposure of zebrafish to EE2}

Vtg in plasma samples from zebrafish exposed to a range of concentrations of EE2 were assayed by ELISA using either $\mathrm{scFv}$ antibody $\mathrm{H} 4$ or a rabbit polyclonal antiserum against Vtg for comparison. The use of the rabbit antiserum to quantify Z-Vtg in plasma was described previously (Liao et al. 2006). A standard curve of ELISA signal versus concentration of purified Z-Vtg was constructed for each antibody (Fig. 5A). In this assay system, the rabbit antiserum appeared to be more sensitive than $\mathrm{H} 4$ in detecting Z-Vtg in terms of threshold levels required to produce a signal above background or required to produce a half-saturation ELISA signal. This may reflect the difference between the polyclonal rabbit serum, which may recognize multiple epitopes, and the monoclonal scFv antibody $\mathrm{H} 4$. ELISA signals were determined for dilution series of each plasma sample using $\mathrm{H} 4$ or the rabbit antiserum. The curves for sera from fish exposed to the highest concentration of EE2 are illustrated (Fig. 5B). As was the case for purified Vtg, the rabbit antiserum appeared to detect Vtg in serum more sensitively than H4. Both antibodies showed a low background signal for samples of plasma from control juvenile male fish that had been exposed to DMSO only. The appropriate standard curve was used to estimate the Z-Vtg concentration of each serum sample (Fig. 5C). As estimated by antibody H4, serum Vtg appeared to increase continu- 

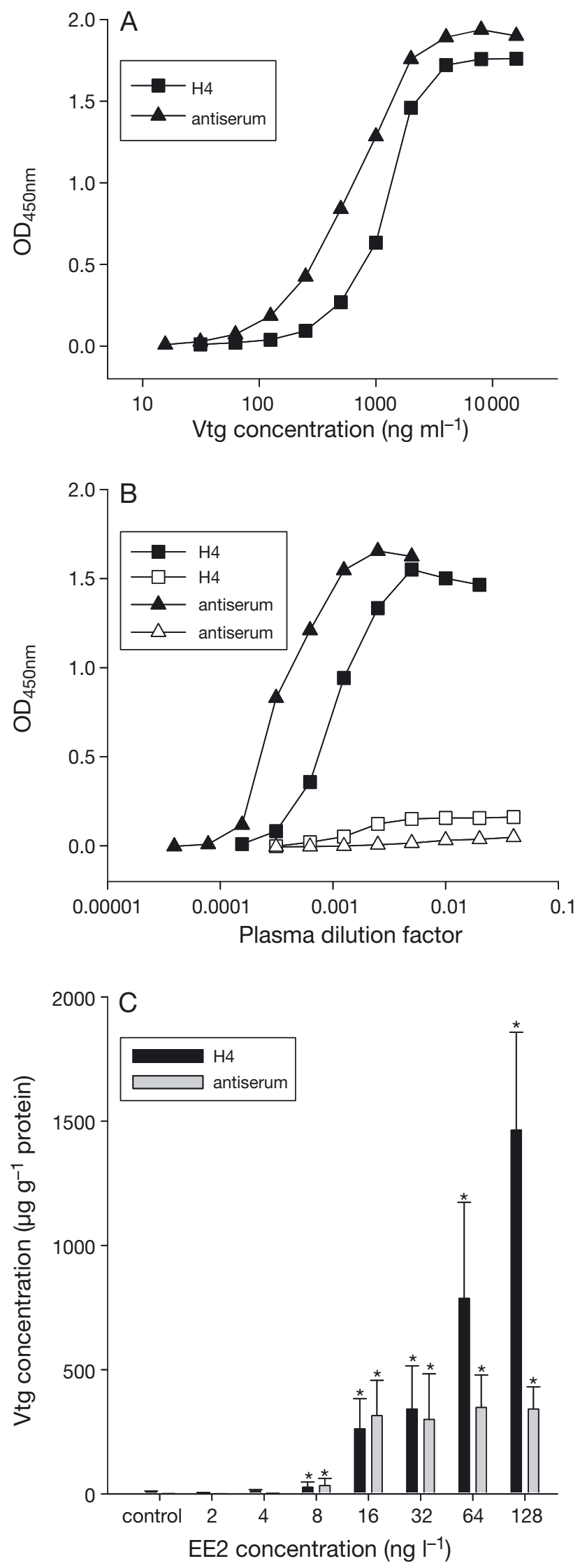

Fig. 5. Vitellogenin (Vtg) bioassay for endocrine-disrupting compounds. (A) ELISA of serial dilutions of purified Vtg with (ם) single-chain variable fragment ( $\mathrm{scFv}$ ) antibody $\mathrm{H} 4$ and (A) rabbit antiserum. (B) ELISA of serial dilutions of plasma from juvenile male zebrafish exposed to $128 \mathrm{ng} \mathrm{l}^{-1} 17 \alpha-$ ethynylestradiol (EE2) for $7 \mathrm{~d}$ with (ם) soluble scFv antibody H4 and ( $\Delta$ ) rabbit antiserum; ELISA of serial dilutions of plasma from unexposed juvenile male zebrafish with $(\square)$ soluble scFv antibody H4 and $(\Delta)$ rabbit antiserum. (C) Determination of Vtg levels in sera from fish exposed to a range of EE2 concentrations. Juvenile zebrafish were exposed to EE2 for $7 \mathrm{~d}$ at the indicated concentrations. ELISA were performed with scFv H4 $\left(25.4 \mu \mathrm{g} \mathrm{ml}^{-1}\right)$ or rabbit antiserum (1:10000). Values are means \pm SD $(n=20)$. ${ }^{*}$ Significant difference from the control at $\mathrm{p}<0.05$

ously with exposure of fish to increased concentrations of EE2 over the range tested. In contrast, as estimated with the rabbit antiserum, Vtg levels appeared to plateau at and above exposure to EE2 at $16 \mathrm{ng} \mathrm{l}^{-1}$. The reason for this is not apparent. A similar result was obtained in an independent experiment in which homogenates of whole fish were assayed for Vtg; however, those samples had higher background signals compared to those from serum samples (data not shown).

\section{CONCLUSION}

In September 2009, the council of OECD adopted the Guidelines for the Testing of Chemicals 229 (Fish short term reproduction assay) and 230 (21-day fish assay: a short term screening for oestrogenic and androgenic activity, and aromatase inhibition). In the 2 test guidelines, Vtg is one of the 2 major endpoint biomarkers measured after an exposure experiment; the other is secondary sexual characteristics.

Vtg has been used as an exposure biomarker for monitoring estrogen and estrogen mimics in surface effluent and reclaimed water from sewage treatment plants (Sumpter \& Jobling 1995, Li et al. 2005, An et al. 2007). Various polyclonal and monoclonal antibodies have been developed for Vtg bioassays for different fish species. But the production of polyclonal and monoclonal antibodies is time-consuming ( 2 to $8 \mathrm{wk}$ ), low yield (e.g. 5 to $10 \mathrm{ml}$ ascites from 1 mouse) and requires culture of eukaryotic cells or animal immunization (Kohler \& Milstein 1975). Compared with polyclonal and monoclonal antibodies, scFv antibodies can be developed quickly from phage-display antibody libraries and produced quickly (within 2 d) in large amounts (10 to $100 \mu \mathrm{g} \mathrm{scFv}$ per ml bacterial culture medium in the present study) in bacterial hosts without animal immunization. These advantages make scFv antibodies cheap to produce. Furthermore, because of the correlation between an observed phe- 
notype and its encapsulated genotype, scFv antibodies can be easily sequenced and modified by gene and protein engineering. $\mathrm{ScFv}$ antibodies have been widely used in variety of applications (Hoogenboom et al. 1998, Bratkoviã 2010).

$\mathrm{ScFv}$ antibodies developed by phage-display technology have not been used previously in Vtg detection. This study succeeded in isolating $\mathrm{ScF}_{\mathrm{V}}$ antibodies that specifically recognized the highly conserved N-terminal fragment (VI) of cyprinid fish Vtg. The scFv antibody $\mathrm{H} 4$ can be used in ELISA to measure Vtg in serum samples from common carp, zebrafish and rare minnow with similar binding specificities and sensitivities. We have shown that it can be used as the basis for a simple and inexpensive assay for Vtg detection of exposure to estrogenic chemicals in these species. However, the sensitivity of $\mathrm{H} 4$ is $50 \mathrm{ng} \mathrm{Vtg} \mathrm{ml}{ }^{-1}$, which is lower than that of other published polyclonal and monoclonal antibodies, for example those reported by An et al. (2007) ( 1 ng Vtg ml $\left.{ }^{-1}\right)$, Nielsen et al. (2004) (0.4 ng Vtg ml-1) and Holbech et al. (2001) (0.2 ng Vtg $\left.\mathrm{ml}^{-1}\right)$. The improvement of $\mathrm{scFv}$ antibody sensitivity using gene and protein engineering technology will be further investigated.

Acknowledgements. This work was funded by National Natural Science Foundation of China grant (20777091) and Chinese 863 program (2006AA06Z424).

\section{LITERATURE CITED}

An LH, Hu JY, Zhu XY, Deng BS, Zhang ZB, Yang M (2007) Crucian carp (Carassius carassius) VTG monoclonal antibody: development and application. Ecotoxicol Environ Saf 66:148-153

Asturiano JF, Romaguera F, Aragón P, Atienza J, Puchades R, Maquieira Á (2005) Sandwich immunoassay for determination of vitellogenin in golden grey mullet (Liza aurata) serum as a field exposure biomarker. Anal Bioanal Chem 381:1152-1160

Barbas CF III, Burton DR, Scott JK, Silverman GJ (2001) Phage display - a laboratory manual. Cold Spring Harbor Laboratory Press, Cold Spring Harbor, NY, p 9.23-29.35

Beatty JD, Beatty BG, Vlahos WG (1987) Measurement of monoclonal antibody affinity by non-competitive enzyme immunoassay. J Immunol Methods 100:173-179

Bratkoviã T (2010) Progress in phage display: evolution of the technique and its applications. Cell Mol Life Sci 67: 749-767

Brion F, Nilsen BM, Eidem JK, Goksøyr A, Porcher JM (2002) Development and validation of an enzyme-linked immunosorbent assay to measure vitellogenin in the zebrafish (Danio rerio). Environ Toxicol Chem 21:1699-1708

Bulukin E, Meucci V, Minunni M, Pretti C, Intorre L, Soldani G, Mascini M (2007) An optical immunosensor for rapid vitellogenin detection in plasma from carp (Cyprinus carpio). Talanta 72:785-790

Colborn T, Dumanoski D, Myers JP (1996) Our stolen future. Dutton, New York, NY
Copeland PA, Sumpter JP, Walker TK, Croft M (1986) Vitellogenin levels in male and female rainbow trout (Salmo gairdneri Richardson) at various stages of the reproductive cycle. Comp Biochem Physiol B 83:487-493

> Darain F, Park DS, Park JS, Shim YB (2004) Development of an immunosensor for the detection of vitellogenin using impedance spectroscopy. Biosens Bioelectron 19: 1245-1252

Denslow ND, Chow MC, Kroll KJ, Green L (1999) Vitellogenin as a biomarker of exposure for estrogen or estrogen mimics. Ecotoxicology 8:385-398

Eidem JK, Kleivdal H, Kroll K, Denslow N and others (2006) Development and validation of a direct homologous quantitative sandwich ELISA for fathead minnow (Pimephales promelas) vitellogenin. Aquat Toxicol 78:202-206

Fenske M, van Aerle R, Brack S, Tyler CR, Segner H (2001) Development and validation of a homologous zebrafish (Danio rerio Hamilton-Buchanan) vitellogenin enzymelinked immunosorbent assay (ELISA) and its application for studies on estrogenic chemicals. Comp Biochem Physiol C 129:217-232

Finn RN (2007) Vertebrate yolk complexes and the functional implications of phosvitins and other subdomains in vitellogenins. Biol Reprod 76:926-935

Folmar LC, Denslow ND, Wallace RA, Lafleur G, Gross TS, Bonomelli S, Sullivan CV (1995) A highly conserved Nterminal sequence for teleost vitellogenin with potential value to the biochemistry, molecular biology and pathology of vitellogenesis. J Fish Biol 46:255-263

- Folmar LC, Denslow ND, Rao V, Chow M and others (1996) Vitellogenin induction and reduced serum testosterone concentrations in feral male carp (Cyprinus carpio) captured near a major metropolitan sewage treatment plant. Environ Health Perspect 104:1096-1101

Fukada H, Fujiwara Y, Takahashi T, Hiramatsu N, Sullivan CV, Hara A (2003) Carp (Cyprinus carpio) vitellogenin: purification and development of a simultaneous chemiluminescent immunoassay. Comp Biochem Physiol A 134: $615-623$

Harlow E, Lane D (1999) Using antibodies: a laboratory manual. Cold Spring Harbor Laboratory Press, Cold Spring Harbor, NY

Hennies M, Wiesmann M, Allner B, Sauerwein H (2003) Vitellogenin in carp (Cyprinus carpio) and perch (Perca fluviatilis): purification, characterization and development of an ELISA for the detection of estrogenic effects. Sci Total Environ 309:93-103

> Heppell SA, Denslow ND, Folmar LC, Craig VS (1995) Universal assay of vitellogenin as a biomarker for environmental estrogens. Environ Health Perspect 103:9-15

Holbech H, Andersen L, Petersen GI, Korsgaard B, Pedersen KL, Bjerregaard P (2001) Development of an ELISA for vitellogenin in whole body homogenate of zebrafish (Danio rerio). Comp Biochem Physiol C 130:119-131

Hoogenboom HR, de Bruine AP, Hufton SE, Hoet RM, Arends JW, Roovers RC (1998) Antibody phage display technology and its applications. Immunotechnology 4:1-20

Jobling S, Nolan M, Tyler CR, Brighty G, Sumpter JP (1998) Widespread sexual disruption in wild fish. Environ Sci Technol 32:2498-2506

> Kang BJ, Jung JH, Lee JM, Lim SG and others (2007) Structural and expression analyses of two vitellogenin genes in the carp, Cyprinus carpio. Comp Biochem Physiol B 148: $445-453$

- Kohler G, Milstein C (1975) Continuous cultures of fused cells secreting antibody of predefined specificity. Nature 256: 495-497 
Li CR, Kim KT, Kang YJ, Kim A, Kang SW, Park JS (2005) A novel enzyme-linked immunosorbent assay system for the quantitative analysis of Carassius auratus vitellogenin. Chemosphere 59:997-1003

Liao T, Jin S, Yang F, Hui Y, Xu Y (2006) An enzyme-linked immunosorbent assay for rare minnow (Gobiocypris rarus) vitellogenin and comparison of vitellogenin responses in rare minnow and zebrafish (Danio rerio). Sci Total Environ 364:284-294

Ma T, Gong S, Wan X, Wang Z, Liu J (2005) Electrophoretic characterization of Gobiocypris rarus vitellogenin. Chin High Technol Lett 15:93-96

Muncke J, Eggen RL (2006) Vitellogenin 1 mRNA as an early molecular biomarker for endocrine disruption in developing zebrafish (Danio rerio). Environ Toxicol Chem 25: $2734-2741$

Mylchreest E, Snajdr S, Korte JJ, Ankley GT (2003) Comparison of ELISAs for detecting vitellogenin in the fathead minnow (Pimephales promelas). Comp Biochem Physiol C 134:251-257

Nilsen BM, Berg K, Eidem JK, Kristiansen SI, Brion F, Porcher JM, Goksøyr A (2004) Development of quantitative vitellogenin-ELISAs for fish test species used in endocrine disruptor screening. Anal Bioanal Chem 378:621-633

OECD (2009a) OECD Guidelines for the testing of chemicals 229. Fish short term reproduction assay. OECD, Paris

OECD (2009b) OECD Guidelines for the testing of chemicals 230. 21-day fish assay: a short term screening for oestrogenic and androgenic activity, and aromatase inhibition. OECD, Paris

Panter GH, Hutchinson TH, Länge R, Lye CM, Sumpter JP, Zerulla M, Tyler CR (2002) Utility of a juvenile fathead

Editorial responsibility: Thomas Braunbeck, Heidelberg, Germany minnow screening assay for detecting (anti)-estrogenic substances. Environ Toxicol Chem 21:319-326

Parks LG, Cheek AO, Denslow ND, Heppell SA, McLachlan JA, LeBlanc GA, Sullivan CV (1999) Fathead minnow (Pimephales promelas) vitellogenin: purification, characterization and quantitative immunoassay for the detection of estrogenic compounds. Comp Biochem Physiol C 123: $113-125$

Pereira JJ, Ziskowski J, Mercaldo-Allen R, Kuropat CA, Luedke DA, Gould E (1992) Vitellogenin studies in winter flounder (Pleuronectes americanus) from Long Island Sound and Boston Harbor. Estuaries 15:289-297

Specker JL, Sullivan G (1994) Vitellogenesis in fish: status and perspectives. In: Davey KG, Peter RE, Tobe SS (eds). Perspectives in comparative endocrinology. National Research Council of Canada, Ottawa, p 304-315

Sumpter JP, Jobling S (1995) Vitellogenesis as a biomarker for estrogenic contamination of the aquatic environment. Environ Health Perspect 103(Suppl 7):173-178

> Tyler CR, Sumpter JP (1990) The development of a radioimmunoassay for carp, Cyprinus carpio, vitellogenin. Fish Physiol Biochem 8:129-140

Tyler CR, Eerden B, Sumpter JP, Jobling S, Panter G (1996) Measurement of vitellogenin, a biomarker for exposure to estrogen, in a wide variety of cyprinids. J Comp Physiol B 166:418-426

Wallace RA (1985) Vitellogenesis and oocyte growth in nonmammalian vertebrates. Dev Biol 1:127-177

Zhong X, Xu Y, Liang Y, Liao T, Wang J (2004) Vitellogenin in rare minnow (Gobiocypris rarus): identification and induction by waterborne diethylstilbestrol. Comp Biochem. Physiol C 137:291-298

Submitted: March 16, 2010; Accepted: July 13, 2010 Proofs received from author(s): November 12, 2010 